\title{
THERMAL PERFORMANCE OF EXTERNAL ROLLER BLINDS RETROFIT FOR OFFICES IN THE UNITED KINGDOM
}

\author{
Hanna Ylitalo ${ }^{1}$, Kenneth Ip $^{2}$ \& David Marshall ${ }^{1}$
}

\begin{abstract}
Fixed external shading devices, such as louvres, are widely used to combat solar gains that can lead to excessive overheating. External roller blinds, common in mainland Europe, are rarities in the $U K$.

External roller blinds are retractable shading devices formed of horizontal slats that roll up into a casing above a window opening. They are a well developed technology with distinct advantages over fixed external shading devices. Appropriate design and applications of external roller blinds have the potential to improve the sustainability of buildings.

This paper reports on a proof of concept trial that demonstrates the effect of external roller blinds on the internal thermal environment under UK climate. An external roller blind was installed in a test room and its impact on internal mean radiant temperature was compared to an internal venetian blind in a control room. Real time monitoring was carried out over the summer in 2011. A computer thermal model was established to model the test room and to simulate the impact of the external roller blind on the cooling load.

This paper concludes that external roller blinds have the potential to reduce summertime mean temperature by $1.8^{\circ} \mathrm{C}$ and lower peak temperature by $3.5^{\circ} \mathrm{C}$. Cooling load can be reduced by $20 \%$. The research to demonstrate their potential is on-going.
\end{abstract}

Keywords: External roller blinds, shading device, solar control, glazed windows, summer overheating.

\section{Introduction}

There is a growing demand for strategies to combat excessive solar gains in buildings. Effective shading can reduce summertime overheating, regulate swings in temperature that occur on sunny days and generally benefit the indoor thermal environment. The England and Wales Building Regulations (HM Government, 2010) recommend the use of solar shading and include an explicit requirement to limit heat gains to new buildings.

Windows are usually the weakest thermal element in the building envelope, and one of the most common causes of overheating is excessive solar gain through windows. Therefore reducing solar gain though windows is a key consideration in maintaining comfortable indoor temperature and implementing low energy building design. In comparison to mechanical cooling, shading is a more energy efficient and cost effective way to control overheating (CIBSE, 2006; Littlefair, 2002; 2006). Shading is an integral part of building design and should be considered from early design stages.

\footnotetext{
${ }^{1}$ Alonso Marshall Associates, No. 5 Level 5 South, New England House, New England Street, Brighton BN1 4HG, East Sussex, United Kingdom, E-mail: hanna@amaconsult.co.uk, davidj@amaconsult.co.uk.

${ }^{2}$ Centre for Sustainability of the Built Environment, School of Environment and Technology, University of Brighton, Cockcroft Building, Lewes Road, Brighton BN2 4GJ, East Sussex, United Kingdom, E-mail: k.ip@brighton.ac.uk.
} 


\section{Background}

Solar control addresses three types of solar radiation. Direct radiation emanates straight from the sun and is the most significant radiation to control to reduce overheating. Diffuse radiation emanates from all angles within the horizons and has less impact on overheating. Reflected radiation is reflected from ground and buildings and comprises both direct and diffuse radiation.

The solar radiation transmitted by and absorbed within the glazing system establishes the level of solar gain in a space (CIBSE, 2006). External shading is more effective than internal shading in reducing overheating as most of the heat in solar radiation is prevented form reaching a building surface. According to Wulfinghoff (1999) external shading can reduce solar heat input by $80 \%$ to $90 \%$. Detailed design, in particular of fixed systems, is required to ensure heating and lighting demand is not increased as incoming daylight is blocked and useful winter solar gain can be reduced (Littlefair 2002; 2006). The need for shading is not the same throughout the year; variation comes from seasonal requirements, daily weather and occupant requirement. Therefore moveable devices that can respond to the climate and user needs are preferred.

External retractable shading devices can be used to avoid the compromise between adequate shading in summer and adequate sun access in winter, however ventilation requirements should be taken into consideration when full shading is required during periods of overheating (Stack et al., 2000).

\section{External roller blind}

External roller blinds are retractable shading devices that are widely used in continental Europe. They provide solar control and reduce heat gains by blocking solar radiation externally. In a down position the blind increases thermal resistance, resulting from both the blind itself and the additional air layer enclosed between the window.

There are two main system types: retrofit and compact. The retrofit system in Fig. 1 is where the blind mechanism is fixed to the exterior of the building with access to roller casing and all components externally. The compact system is where the blind is part of the window system, housed in a lintel box, with internal access to all components. They have two different operating systems, manual belt driven or motorised. Motorised blinds can be automated via a building management system, or by local control using wireless handheld device or wall mounted switch.
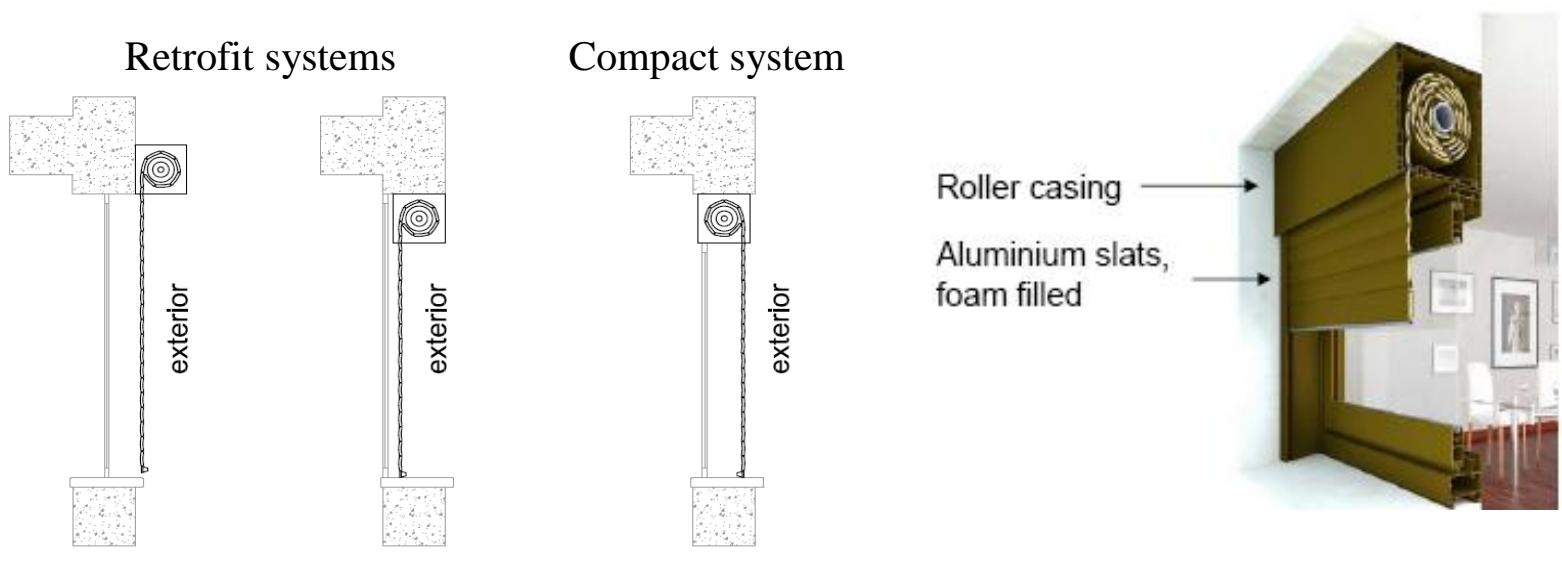

Fig. 1. Section through external roller blind (Aluplex, 2012) 
The slats that form the shutter are commonly foam filled extruded aluminium slats or hollow profile slats. The thermal capacity of the blind is determined by the thickness of the slat and density of the polyurethane insulating foam. Standard extruded slat has a nominal thickness of $7 \mathrm{~mm}$ and polyurethane foam density of $70 \mathrm{~kg} / \mathrm{m}^{3}$. High performance slats have nominal thickness of up to $8.5 \mathrm{~mm}$ and foam density of $200 \mathrm{~kg} / \mathrm{m}^{3}$ (Aluplex, 2012). The design profile, width and curvature of the slat determine its rolling capacity and therefore the size of the roller casing.

External roller blinds have a range of different insulating properties; thermal and acoustic insulation, resistance to wind and water. They reduce heat losses in winter and heat gain in summer. In a down position access to natural light and ventilation can be restricted. External roller blinds are commonly used with windows that open inwards or that have a sliding opening mechanism.

The term external roller blind is not standardised and the system can be referred to by a different name, these include external rolling shutters, external roller shutters or external roller blind shutters (Littlefair, 1999), external retractable shutters (Stack et al., 2002), external solar blinds or external solar shutters (Standaert, 2006).

\section{Quantifying shading}

External blinds provide additional insulation due to the air enclosed between the window and the blind. The degree of insulation depends on the level of enclosure, the effective entrapment by top and bottom seals and side channels (CIBSE, 2006). EN ISO 100771:2006 gives the thermal transmittance of a window with closed external blind, $U_{W S}$, as:

$$
U_{W S}=\frac{1}{1 / U_{W}+\Delta \mathrm{R}}
$$

$U_{W} \quad$ thermal transmittance of window;

$\Delta R \quad$ additional thermal resistance due to the air layer enclosed between the shutter and the window and the closed shutter itself.
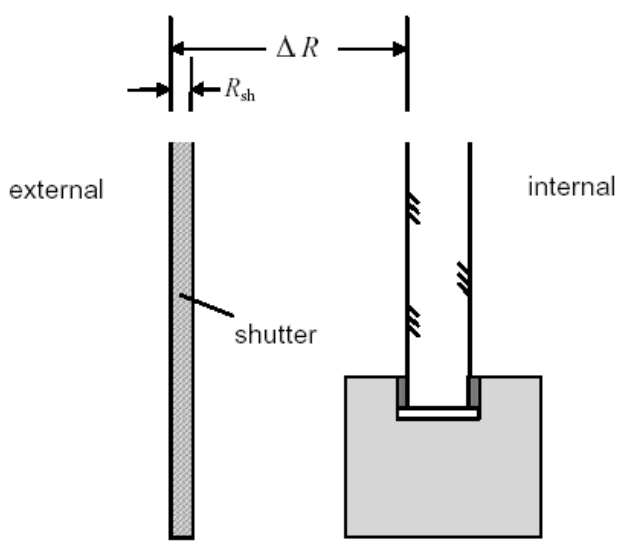

Fig. 2. Thermal transmittance of a window with a closed external shutter (BSI, 2006)

On a clear day in summer an unshaded window in the UK can admit $3 \mathrm{kWh} / \mathrm{m}^{2} / \mathrm{day}$ (Littlefair, 1999). To reduce overheating, a shading device should have a low total solar transmittance, or g-value; the fraction of incoming solar radiation that passes through a window and shading system. It includes both radiation that is transmitted directly through the window, and radiation that is absorbed; and the re-radiated, convected or conducted

Solar gain in period of potential overheating through window with shading device heat into the room. The effective solar $g_{\text {eff }}=\frac{\text { Solar gain through unshaded, unglazed }}{\text { Saphe }}$ transmittance, or effective g-value $g_{\text {eff }}$, allows for the effects of radiation coming in from different angles, throughout a sunny day. It takes account aperture for the same period of the extra radiation blocked by a shading device (CIBSE, 2006).

The shading coefficient expresses the solar transmittance as a fraction. It is the ratio of the instantaneous heat gain at normal incidence transmitted by a particular glass and blind 
combination to that for unshaded single glazing (CIBSE, 2006; Littlefair, 2002). Shading coefficient is calculated as:

Solar gain through subject glass and blind at direct normal incidence $S C=$

Solar gain through reference glass at direct normal incidence where the solar gain through reference glass at direct normal incidence is 0.87 .

Solar gain can be considered to mean the shortwave or the longwave component, or the total of both.

\section{Existing research}

Research on solar shading has been conducted using experimental or simulation techniques. Real time tests are mainly performed on existing buildings and can be expensive and time consuming. Computer simulation has gained acceptance and is considered a true prediction of real performance of buildings, however it is imperative that software is validated and the user is proficient (Hammad and Abu-Hijleb, 2010; Nielsen et al., 2011: Tzempelikos and Athienitis, 2006).

The thermal impact of various external shading devices, such as dynamic and retractable external shading (Nielsen et al., 2011), dynamic external louvres (Hammad and Abu-Hijleb, 2010), external mobile shading (van Moeseke et al., 2005), horizontal and vertical louvres (Palmero-Marrero and Oliveira, 2009), fabric exterior roller shade (Tzempelikos and Athienitis, 2006), exterior venetian blind (Loutzenhiser et al., 2008), as shown in Fig.3, has been studied. Focus of these studies is on reducing summer overheating without blocking out useful daylight. Many shading systems are dynamic; they operate automatically in response to solar radiation levels and are often connected to lighting system that can automatically dim when natural light is sufficient.
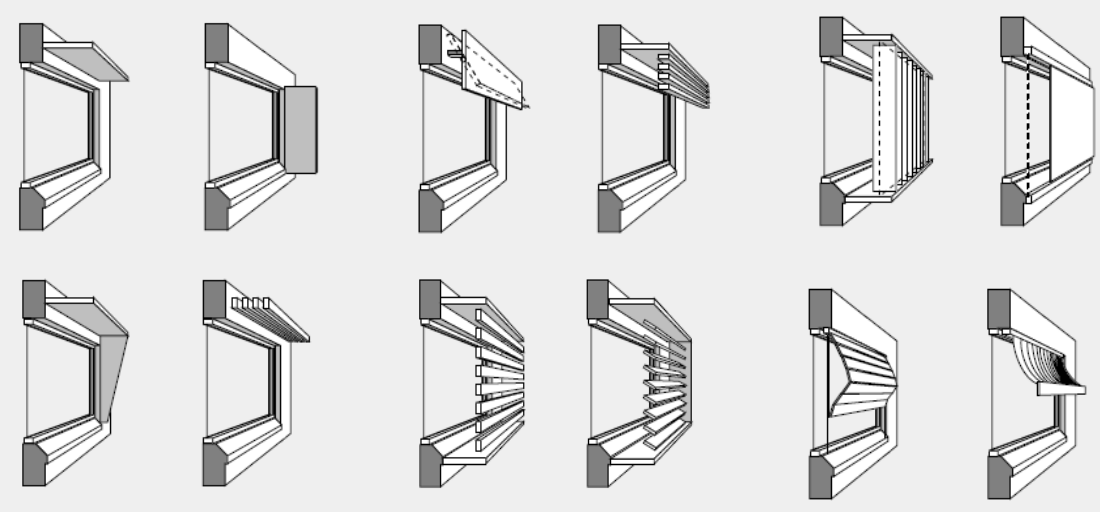

Fig. 3. External shading devices (Stack et al. 2000)

Some existing research quantifies the thermal impact of shading devices. Automated external fabric roller blind was discovered by Tzempelikos and Athienitis (2006) to reduce cooling energy demand by $50 \%$ in comparison to no shading, however heating demand was increased depending on location. Study by Standaert (2006) concluded that external roller blinds could reduce heating energy demand by $10 \%$ in climate similar to that in UK and the need for active cooling could be voided in some cases.

No current existing research focuses solely on the thermal performance of external roller blinds and their suitability for UK climate or test on their effect on reducing overheating in the UK. 


\section{Experimental setup}

A concept trial was conducted with the aim to determine the shading effect of an external roller blind. The experiment was carried out in an unoccupied room, facing southwest, at University of Brighton, southeast England, between $10^{\text {th }}$ and $30^{\text {th }}$ August 2011.

The room was partitioned into three compartments, Fig. 4; entrance area, control room and test room. Control room and test room were $2.9 \mathrm{~m}$ wide by $5.7 \mathrm{~m}$ deep, total floor area $16.53 \mathrm{~m}^{2}$ each, height to suspended ceiling $3.5 \mathrm{~m}$.

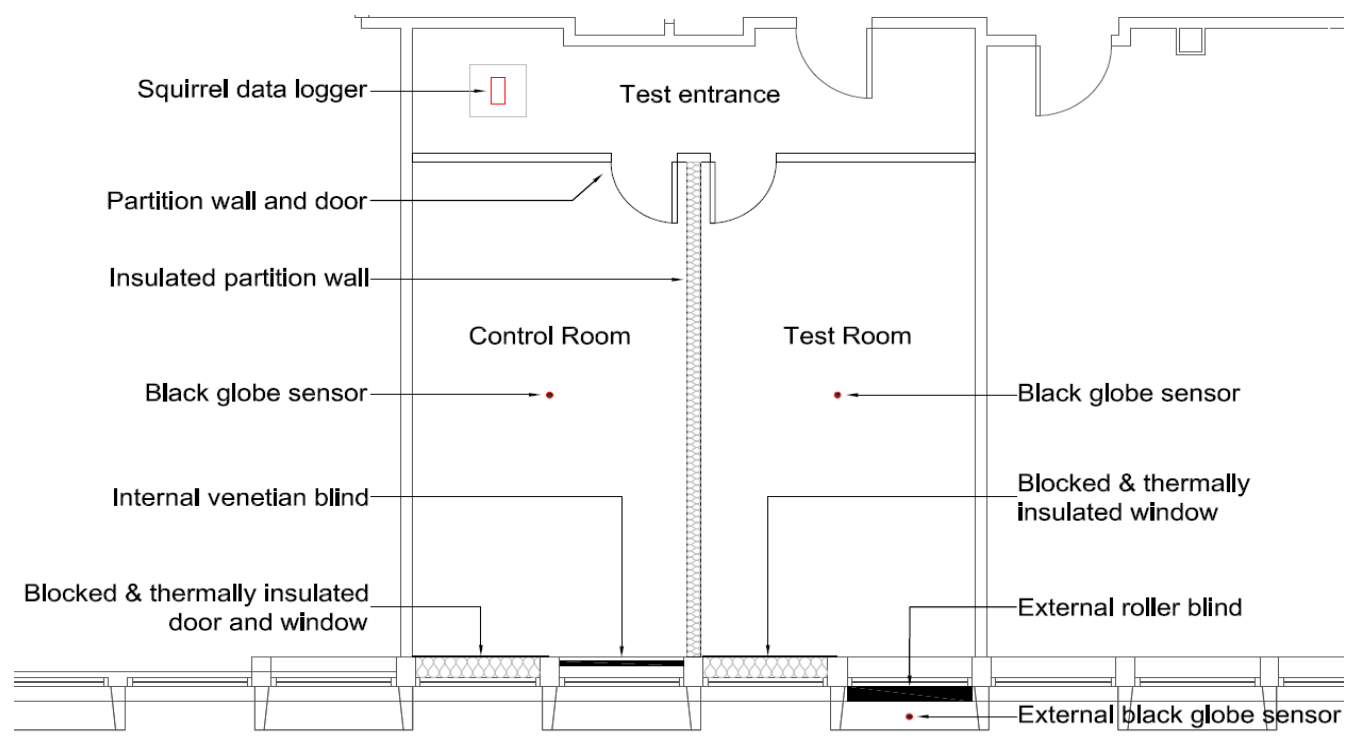

Fig. 4. Floor plan of experimental setup

Each room had two windows with boxed type projection fins, one of which was blocked and thermally insulated. The remaining window, $1.3 \mathrm{~m}$ wide by $2.3 \mathrm{~m}$ high, was installed with either an internal venetian blind or an external roller blind. Windows remained closed during the trial. Blind positions were set manually to achieve an internal daylight level of 300lux at midday, to achieve visual comfort in offices (CIBSE, 2006). This set the external roller blind $650 \mathrm{~mm}$ open from the base. Rooms contained a small amount of office type furniture, the lights were switched off and no equipment was present. Fig. 5 shows the internal view towards window in test room and Fig. 6 in control room.

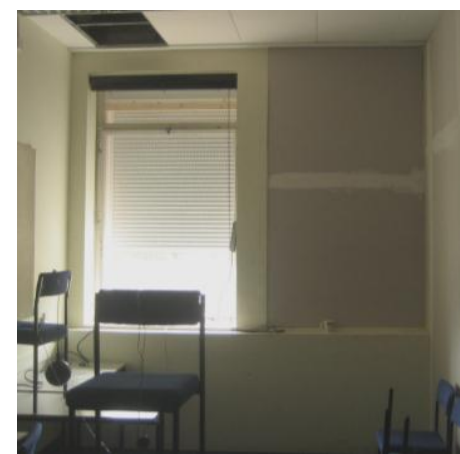

Fig. 5. Test room

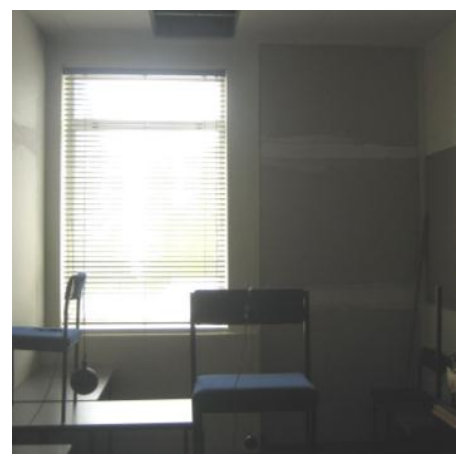

Fig. 6. Control room

Interior building elements are adjacent to occupied spaces and the exterior wall is not shaded. Mean radiant temperature was measured in both rooms by Type $K$, $\varnothing 50 \mathrm{~mm}$ black 
globe thermocouple located in the centre of each room at $600 \mathrm{~mm}$ height from floor level. External mean radiant temperature was measured below test room window (Fig. 7).

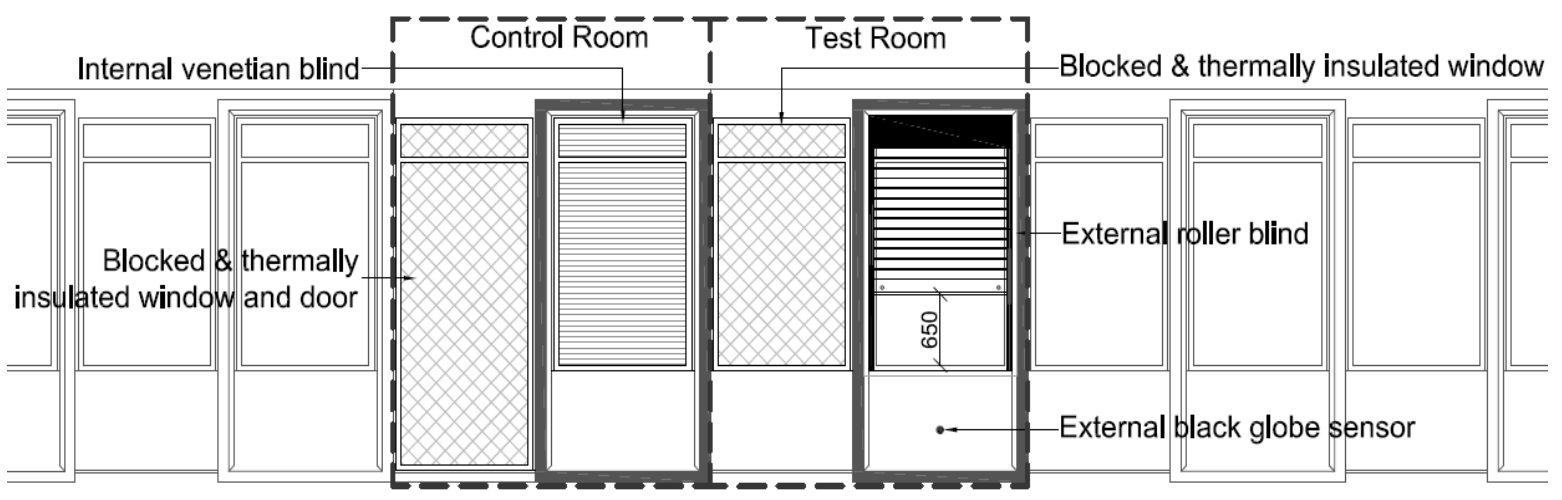

Fig. 7. External elevation of experimental setup

Temperatures were automatically logged every five minutes by Squirrel Data Logger, located in test entry area. Apparatus was calibrated by Building Services Research and Information Association. Meteorological data is from a local weather station at Shoreham Airport $13 \mathrm{~km}$ from test site (Weather Underground, 2011).

\section{Experimental results}

The mean radiant temperature was recorded at five minute intervals during the test, the data was then simplified to hourly mean data. Local meteorological data was collated and processed to hourly record of external air temperature and observed weather conditions.

Fig. 8 shows control room mean radiant temperature (mrt), test room mean radiant temperature, external mean radiant temperature and external air temperature over the test period. Highest temperatures were recorded between days 11 and 12, highlighted as A, an exception to this was day 6 when test room temperature reached its peak, highlighted as B. For all the four measurements, the lowest temperatures were recorded during day 20 , highlighted as $\mathrm{C}$.

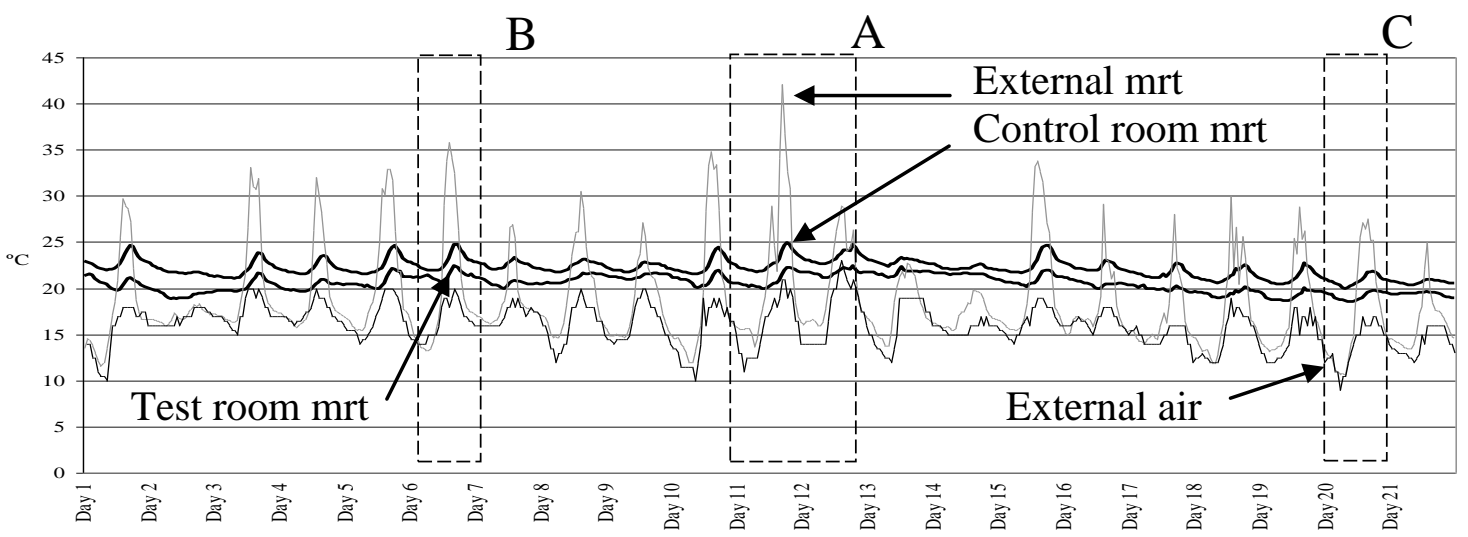

Fig. 8. Experimental study daily temperature graph

Test room temperature was lower than control room temperature throughout the test. Daily temperature peaks occurred an hour later in test room than control room. Indoor temperature peaks were recorded after external temperature peaks. 


\section{Temperature occurrence}

Frequency of temperature occurrence has been established for both rooms, as shown in Fig. 9. Temperature range recorded in control room was broader than in test room; control room temperature range varied from $20^{\circ} \mathrm{C}$ to $24.9^{\circ} \mathrm{C}$, test room range varied from $18.6^{\circ} \mathrm{C}$ to $22.5^{\circ} \mathrm{C}$

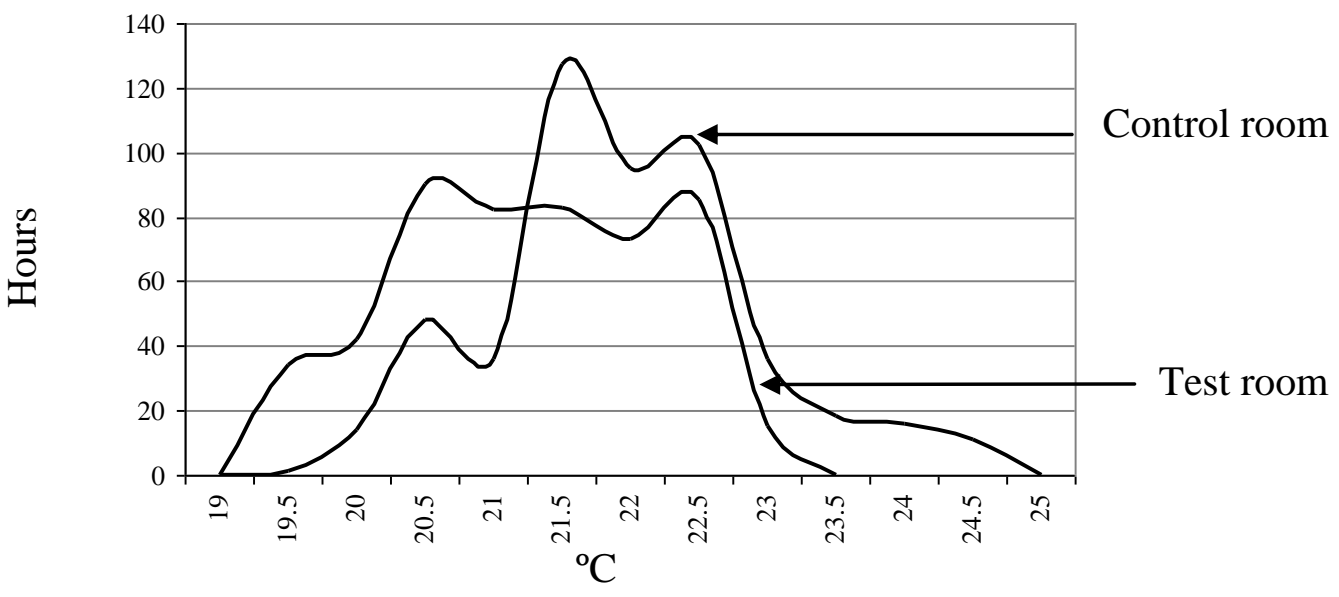

Fig. 9. Room temperature range frequency

Test room temperature was commonly within a temperature range of $20^{\circ} \mathrm{C}$ to $22^{\circ} \mathrm{C}$, this occurred $68 \%$ of the time, for 343 hours, whereas control room temperature was in this range $45 \%$ of the time, for 226 hours. Control room temperature was commonly within a temperature range between $22^{\circ} \mathrm{C}$ and $23^{\circ} \mathrm{C}$, this occurs $64 \%$ of the time, for 324 hours. Temperature graphs show that test room temperature levels out at a lower temperature and has temperature peaks closer to the trend during the trial.

Maximum temperature in test room is $2.4^{\circ} \mathrm{C}$ lower than in control room, indicating that external roller blind is regulating the level of solar gain and peak temperatures.

Minimum temperature in test room is $1.5^{\circ} \mathrm{C}$ lower than in control room. This indicates that higher level of solar gain is entering the room and the thermal mass of the building is retaining heat. This can be beneficial during winter months when passive heating is useful.

\section{Weather conditions}

The experiment was carried out in rooms facing southwest, where the sun is directly opposite between 14.00 and 15.00. Weather conditions for hours between 13.00 and 16.00 were considered to have an effect and were analysed.

Afternoon weather conditions were 'partly cloudy' or 'scattered clouds' $73 \%$ of the time. Day 12 had two continuous 'clear' hours, during these hours maximum external air temperature of $23.0^{\circ} \mathrm{C}$ was recorded. Later that day, between 18.00 to 19.00 test room maximum mean radiant temperature of $22.5^{\circ} \mathrm{C}$ was recorded. Day 14 was 'mainly cloudy', resulting in lower temperature peaks in both rooms.

The results suggest that sunny weather results in higher indoor temperatures. Due to lack of variation in weather conditions further analysis was not possible.

\section{Day and night time temperature}

Temperature data has been organised to daytime; $8 \mathrm{am}$ to $6 \mathrm{pm}$, representing office occupation hours, and night time; $6 \mathrm{pm}$ to $8 \mathrm{am}$, taken as non working hours. 
Internal temperature does not vary greatly between day and night. However it is to be noted that early evening and early morning hours are generally similar in temperature to daytime hours, thus having an effect.

External temperature has more variance, in particular external mean radiant temperature, where day and night temperature range varies by $7.8^{\circ} \mathrm{C}$. Table 1 is summary of recoded temperatures, day of minimum and maximum temperature occurrence is shown in brackets.

Table 1. Summary of experimental study temperature data

\begin{tabular}{|c|c|c|c|c|c|c|}
\hline \multicolumn{2}{|c|}{$\begin{array}{l}\text { Temperature } \\
\text { (mean radiant) }\end{array}$} & $\begin{array}{l}\text { Control } \\
\text { room }\end{array}$ & $\begin{array}{l}\text { Test } \\
\text { room }\end{array}$ & $\begin{array}{l}\text { Room } \\
\text { difference }\end{array}$ & External & $\begin{array}{l}\text { External } \\
\text { air }\end{array}$ \\
\hline \multirow[t]{3}{*}{ Mean } & 24 hour & $22.2^{\circ} \mathrm{C}$ & $20.5^{\circ} \mathrm{C}$ & $1.7^{\circ} \mathrm{C}$ & $18.8^{\circ} \mathrm{C}$ & $16.0^{\circ} \mathrm{C}$ \\
\hline & Day & $22.2^{\circ} \mathrm{C}$ & $20.4^{\circ} \mathrm{C}$ & $1.8^{\circ} \mathrm{C}$ & $22.2^{\circ} \mathrm{C}$ & $17.3^{\circ} \mathrm{C}$ \\
\hline & Night & $22.1^{\circ} \mathrm{C}$ & $20.6^{\circ} \mathrm{C}$ & $1.6^{\circ} \mathrm{C}$ & $15.0^{\circ} \mathrm{C}$ & $15.0^{\circ} \mathrm{C}$ \\
\hline \multirow[t]{3}{*}{ Max } & 24 hour & $\begin{array}{l}24.9^{\circ} \mathrm{C} \\
\text { (day } 11 \text { ) }\end{array}$ & $\begin{array}{l}22.5^{\circ} \mathrm{C} \\
(\text { day } 6 / 12)\end{array}$ & $3.6^{\circ} \mathrm{C}$ & $\begin{array}{l}42.1^{\circ} \mathrm{C} \\
\text { (day } 11 \text { ) }\end{array}$ & $\begin{array}{l}23.0^{\circ} \mathrm{C} \\
\text { (day } 12 \text { ) }\end{array}$ \\
\hline & Day & $\begin{array}{l}24.7^{\circ} \mathrm{C} \\
(\text { day } 11)\end{array}$ & $\begin{array}{l}22.5^{\circ} \mathrm{C} \\
(\text { day } 6)\end{array}$ & $3.5^{\circ} \mathrm{C}$ & $\begin{array}{l}42.1^{\circ} \mathrm{C} \\
(\text { day } 11)\end{array}$ & $\begin{array}{l}23.0^{\circ} \mathrm{C} \\
\text { (day } 12)\end{array}$ \\
\hline & Night & $\begin{array}{l}24.9^{\circ} \mathrm{C} \\
\text { (day } 11 \text { ) }\end{array}$ & $\begin{array}{l}22.5^{\circ} \mathrm{C} \\
\text { (day } 12 \text { ) }\end{array}$ & $3.6^{\circ} \mathrm{C}$ & $\begin{array}{l}32.7^{\circ} \mathrm{C} \\
(\text { day } 11)\end{array}$ & $\begin{array}{l}20.0^{\circ} \mathrm{C} \\
(\text { day } 11 / 12)\end{array}$ \\
\hline \multirow[t]{3}{*}{ Min } & 24 hour & $\begin{array}{l}20.0^{\circ} \mathrm{C} \\
\text { (day 20) }\end{array}$ & $\begin{array}{l}18.6^{\circ} \mathrm{C} \\
(\text { day } 20)\end{array}$ & $0.4^{\circ} \mathrm{C}$ & $\begin{array}{l}10.6^{\circ} \mathrm{C} \\
(\text { day } 20)\end{array}$ & $\begin{array}{l}9.0^{\circ} \mathrm{C} \\
(\text { day } 20)\end{array}$ \\
\hline & Day & $\begin{array}{l}20.0^{\circ} \mathrm{C} \\
\text { (day 20) }\end{array}$ & $\begin{array}{l}18.6^{\circ} \mathrm{C} \\
(\text { day } 20)\end{array}$ & $0.4^{\circ} \mathrm{C}$ & $\begin{array}{l}12.3^{\circ} \mathrm{C} \\
(\text { day } 20)\end{array}$ & $\begin{array}{l}12.0^{\circ} \mathrm{C} \\
(\text { day } 20)\end{array}$ \\
\hline & Night & $\begin{array}{l}20.0^{\circ} \mathrm{C} \\
\text { (day 20) }\end{array}$ & $\begin{array}{l}18.7^{\circ} \mathrm{C} \\
\text { (day } 19 / 20)\end{array}$ & $0.5^{\circ} \mathrm{C}$ & $\begin{array}{l}10.6^{\circ} \mathrm{C} \\
(\text { day } 20)\end{array}$ & $\begin{array}{l}9.0^{\circ} \mathrm{C} \\
(\text { day } 20)\end{array}$ \\
\hline \multirow[t]{3}{*}{ Swing } & 24 hour & $4.9^{\circ} \mathrm{C}$ & $3.9^{\circ} \mathrm{C}$ & $3.2^{\circ} \mathrm{C}$ & $31.5^{\circ} \mathrm{C}$ & $14.0^{\circ} \mathrm{C}$ \\
\hline & Day & $4.7^{\circ} \mathrm{C}$ & $3.9^{\circ} \mathrm{C}$ & $3.1^{\circ} \mathrm{C}$ & $29.8^{\circ} \mathrm{C}$ & $11.0^{\circ} \mathrm{C}$ \\
\hline & Night & $4.9^{\circ} \mathrm{C}$ & $3.8^{\circ} \mathrm{C}$ & $3.1^{\circ} \mathrm{C}$ & $22.0^{\circ} \mathrm{C}$ & $11.0^{\circ} \mathrm{C}$ \\
\hline
\end{tabular}

The results show different temperature profiles for test room and control room. Test room temperature is continuously lower than control room temperature, in particular maximum temperature and temperature swing are lower in room with external roller blind.

Mean temperature difference is $1.8^{\circ} \mathrm{C}$ during the day, maximum temperature difference is $3.6^{\circ} \mathrm{C}$, minimum temperature difference is $0.5^{\circ} \mathrm{C}$ and mean temperature swing is $3.2^{\circ} \mathrm{C}$ less in test room.

\section{Simulation modelling}

Thermal simulation was carried out for three purposes; to model trial conditions; to predict internal thermal conditions and to predict the impact of an external roller blind on cooling load. IES Virtual Environment software was used to created 3D model of the experiment and to carry out thermal simulations.

\section{Simulation setup}

ModelIT component of the software was used to create a 3D model of the experimental set up. SunCast analysis was run to include the effect of solar shading devices. ApacheSim was run to carry out dynamic thermal simulation. 
Fig.10 is the IES VE 3D model. Following parameters were used for simulation:

- External wall: $300 \mathrm{~mm}$ concrete, cavity, concrete block, U-value $1.06 \mathrm{~W} / \mathrm{m}^{2} \mathrm{~K}$;

- Internal partition: $120 \mathrm{~mm}$ plasterboard, glass fibre quilt, plasterboard, U-value $0.34 \mathrm{~W} / \mathrm{m}^{2} \mathrm{~K}$;

- Internal ceiling/ floor: carpet, screed, concrete, cavity, ceiling tiles, $\mathrm{U}$-value $1.0687 \mathrm{~W} / \mathrm{m}^{2} \mathrm{~K}$;

- Gazing surface: Single glazed, $6 \mathrm{~mm}$, metal frame, U-value $5.56 \mathrm{~W} / \mathrm{m}^{2} \mathrm{~K}$;

- External shading device: left and right fin projection 500mm, offset $0 \mathrm{~mm}$;

- External roller blind: night time and daytime resistance $2.5 \mathrm{~W} / \mathrm{m}^{2} \mathrm{~K}$;

- Internal venetian blind: shading coefficient 0.61 , short-wave radiant fraction 0.4 ;

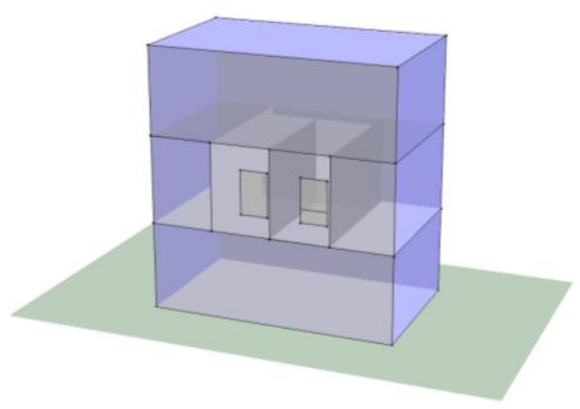

Fig. 10. IES VE 3D model

- No internal gains, heating or cooling;

- Weather data: Heathrow, $71 \mathrm{~km}$ from test site.

\section{Simulation results}

Results include simulation of room temperatures, prediction of internal thermal conditions and prediction of annual cooling load in test room and control room.

\section{Room temperatures}

Simulation results over the same period of time as in the trial show little variation between room day and night temperatures. The results show different temperature profiles for test room and control room. Test room mean temperature is $0.2^{\circ} \mathrm{C}$ lower, maximum temperature is $1.5^{\circ} \mathrm{C}$ lower and temperature swing is $1.5^{\circ} \mathrm{C}$ less than in control room. Minimum temperature is the same in both rooms. Table 2 is summary of simulation temperature data.

Table 2. Summary of simulation 24 hour temperature data

\begin{tabular}{|l|l|l|l|l|}
\hline $\begin{array}{l}\text { Temperature } \\
\text { (mean radiant) }\end{array}$ & Control room & Test room & $\begin{array}{l}\text { Room } \\
\text { difference }\end{array}$ & $\begin{array}{l}\text { External } \\
\text { dry-bulb }\end{array}$ \\
\hline Mean & $21.2^{\circ} \mathrm{C}$ & $21.0^{\circ} \mathrm{C}$ & $0.2^{\circ} \mathrm{C}$ & $18.3^{\circ} \mathrm{C}$ \\
\hline Max & $26.4^{\circ} \mathrm{C}$ & $24.9^{\circ} \mathrm{C}$ & $1.5^{\circ} \mathrm{C}$ & $29.6^{\circ} \mathrm{C}$ \\
\hline Min & $18.1^{\circ} \mathrm{C}$ & $18.1^{\circ} \mathrm{C}$ & $0^{\circ} \mathrm{C}$ & $12.4^{\circ} \mathrm{C}$ \\
\hline Swing & $8.3^{\circ} \mathrm{C}$ & $6.8^{\circ} \mathrm{C}$ & $1.5^{\circ} \mathrm{C}$ & $17.2^{\circ} \mathrm{C}$ \\
\hline
\end{tabular}

Simulation results show the same temperature trend as monitoring data; room with external roller blind has lower temperatures.

\section{Internal air temperature}

CIBSE (2006) uses operative temperature to establish thermal comfort; operative temperature is the weighted average of indoor mean radiant temperature and indoor air 
temperature. Therefore as internal air temperature was not recorded during the test it was predicted by thermal simulation.

The simulation results did not show notable difference between the two temperatures. Mean temperature difference of IES predicted value of mean radiant temperature and air temperature in both rooms is $0.001^{\circ} \mathrm{C}$. Therefore it was concluded that recorded mean radiant temperature is representative of operative temperature during the test.

\section{Prediction of cooling load}

IES VE simulation has been carried out to predict cooling loads from June to August for both rooms, Fig. 11. Room temperature was set on at $23^{\circ} \mathrm{C}$ and internal gains were added for people $\left(73 \mathrm{~W} /\right.$ person, $10.511 \mathrm{~m}^{2} /$ person), fluorescent lighting $\left(15 \mathrm{~W} / \mathrm{m}^{2}\right)$ and office equipment $\left(12.089 \mathrm{~W} / \mathrm{m}^{2}\right)$. The purpose of the simulation was to give an indication of potential reduction in cooling load with use of external roller blind.

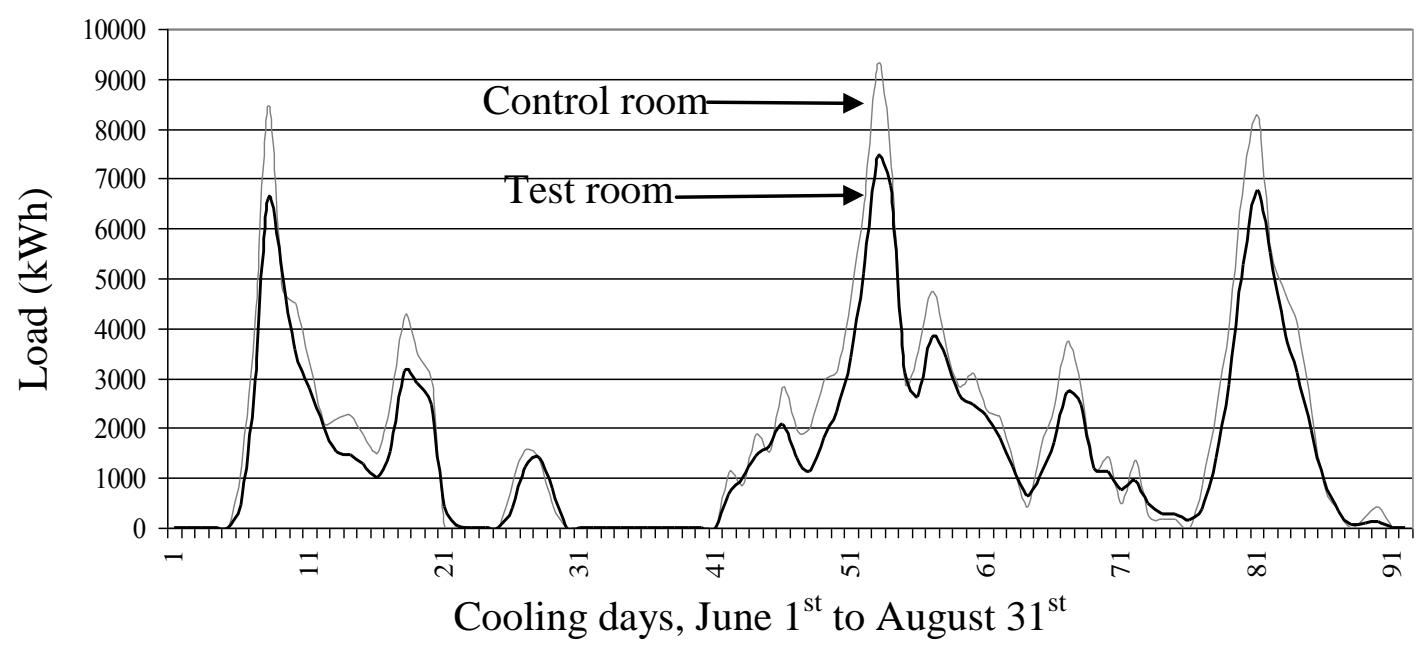

Fig. 11. Cooling load simulation control room and test room comparison

Daily cooling load profiles are different for test room and control room. Control room demand is generally higher and peak cooling demand is higher, potentially having an effect on the size of a comfort cooling system. All monthly cooling load totals are lower in test room; total reduction for the three month period was predicted as $20 \%$. Monthly difference varied; June, July and August reduction was $21 \%, 18 \%$ and $18 \%$ respectively.

The results of the simulation indicate that external roller blind has potential to reduce requirement for cooling and size of potential cooling plant.

\section{Analysis of results and discussion}

The experimental trial set out to demonstrate the thermal impact of external roller blinds. Results show different temperature profiles for the test room and control room; 24 hour data shows that maximum temperature difference between the rooms was $3.6^{\circ} \mathrm{C}$, mean temperature was reduced by $1.7^{\circ} \mathrm{C}$ and temperature swing was $3.2^{\circ} \mathrm{C}$ less.

Analysis of temperature occurrence revealed a difference between the two rooms. In test room the temperature was more constantly at a lower level and within a smaller range. Temperature peaks recorded were lower in temperature and closer to the mean temperature. Test room temperature levelled out at approximately $1^{\circ} \mathrm{C}$ lower than control room temperature, number of hours at a lower temperature range was higher. This would have an effect on thermal comfort and the size of potential cooling system, or possibly 
avoid the need for cooling. Experimental trial results indicate that external roller blinds can reduce the requirement for cooling or it can be avoided.

Results of the experimental trial were organised into day time and night time temperature figures, taken as office occupation hours. However as early evening and early morning temperatures were similar, no great difference was detected between day and night temperatures. In general temperatures were increasing in both rooms towards the end of a working day. The peak temperatures were lower in the room with external roller blind, thus indicating potential for more comfortable thermal conditions.

The building envelope acted as a moderator of weather conditions; external temperature peaks occurred before internal temperature peaks and external temperature range was greater than range experienced indoors. The results also showed that control room, with lower level of solar control, retained a higher temperature over night. This indicates that the thermal mass of the building retained solar gain, something that can be either beneficial or unwanted depending on the season.

Focus of the trial was on summer conditions and reducing overheating. CIBSE (2006) summer operative temperature for non-air conditioned office is $25^{\circ} \mathrm{C}$, benchmark summer peak temperature is $28^{\circ} \mathrm{C}$ and overheating criterion is $1 \%$ annual occupied hours over operative temperature of $28^{\circ} \mathrm{C}$. Therefore it can be concluded that neither room experienced overheating. Control room experienced some high temperatures, it was over $23^{\circ} \mathrm{C}$ for 91 hours during the trial. Test room maximum temperature was $22.5^{\circ} \mathrm{C}$. This range of temperature difference would have an impact on comfort, especially when other gains are added and temperatures are likely to be higher. Therefore it can be concluded that external roller blind has potential to improve thermal comfort and reduce overheating.

The experimental method and simulation method showed the same trend: room with external roller blind experienced lower temperatures. Simulation predicted test room 24 hour mean temperature $0.2^{\circ} \mathrm{C}$ lower and maximum temperature reduction as $1.5^{\circ} \mathrm{C}$.

Cooling load simulation predicted $20 \%$ reduction in cooling load for the test room. This figure is inline with existing research. The indication is that an external roller blind can significantly reduce the requirement for cooling in the UK.

\section{Limitations and future work}

The trial is the first step in a more comprehensive study. Limitations included the lack of indoor air temperature data; relatively short experiment period of 21 days and comparison of two static devices. The rooms were unoccupied with no internal gains thus the results do not reflect a real situation.

Future study in the first instance is to simulate the trial building in more detail and include other parts of the building. Dynamic nature of the external roller blind is to be modelled and its performance will be compared to other shading devices. Software weather data was used for the simulation, to verify the accuracy of the model real time data simulation and subsequent analysis is planned. Study to demonstrate the impact of external roller blind in is winter is to be carried out.

\section{Conclusions}

External roller blinds are movable external shading devices with potential to improve the thermal performance of buildings in the UK climate. An experimental trial concluded that summertime internal temperatures, temperature peaks and temperature swing can be reduced with use of external roller blind. Computer simulation confirms the results of the experiment; external roller blind can be used to reduce, or in some cases, void the 
requirement for active cooling. Thus external roller blinds reduce indoor summertime temperature, requirement for cooling and can improve thermal comfort in buildings.

\section{Acknowledgements}

The authors would like to express their gratitude to Aluplex who provided the external roller blind for the experiment and Mansell Construction Services Ltd who carried out the construction work for the experimental study.

\section{References}

Aluplex, 2012. Available form: http://www.aluplex.se [Site accessed 30 May 2012]

BSI, 2006. BS EN ISO 10077-1:2006. Thermal performance of windows, doors and shutters - Calculation of thermal transmittance - Part 1: General. London: British Standards Institution. ISBN 9780580696428.

CIBSE, 2006. Environmental design CIBSE Guide A. London: The Chartered Institution of Building Services Engineers. ISBN-10: 1-903287-66-9.

Hammad, F. and Abu-Hijleh, B., 2010. The energy saving potential of using dynamic external louvers in an office building. Energy and Buildings, 42(2010), 1888-1895.

HM Government, 2010. Approved Document L2A Conservation of fuel and power in new buildings other than dwellings. London: NBS. ISBN: 9781859463260.

Loutzenhiser, P.G., Manz, H., Carl, S., Simmler, H. and Maxwell, G.M., 2008. Empirical validations of solar gain models for a glazing unit with exterior and interior blind assemblies. Energy and Buildings, 40(2008), 330-340.

Littlefair, P.,1999. Solar shading of buildings BR364. Watford: Building Research Establishment. ISBN 1860812759.

Littlefair, P., 2002. Control of solar shading BRE IP 12/02. Watford: Building Research Establishment. ISBN 1860815847.

Littlefair, P., 2006. Designing for improved solar shading control CIBSE TM37. London: The Chartered Institution of Building Services Engineers. ISBN-10: 1-903287-57-X.

Nielsen, M.V, Svendsen, S. and Jensen, L.B., 2011. Quantifying the potential of automated dynamic solar shading in office buildings through integrated simulations of energy and daylight. Solar Energy, 85 (2011), 757-768.

Palmero-Marrero, A.I. and Oliviera, A.C., 2010. Effect of louver shading devices on building energy requirements. Applied Energy, 87(2010), 2040-2049.

Standaert, P., 2005. Energy saving and CO2 reduction potential from solar shading systems and shutters in the EU-25. Available from: http://www.esso.com/documents/ESCORP-EU25.pdf [Accessed 30 May 2012].

Tzempelikos, A. and Athienitis, A.K., 2006. The impact of shading design and control on building cooling and lighting demand. Solar Energy, 81(2007), 369-382.

van Moeseke, G., Bruyrùe, I. and De Herde, A., 2005. Impact of control rules on the efficiency of shading devices and free cooling in office buildings. Building and Environment, 42 (2007), 784-793.

Stack, A., Goulding, J. and Lewis, O.J., 2000. Shading systems - Solar shading for the European climates. ENERGIE, European Commission. Available from: http://www.esso.com/documents/EurCommOnSolarShading.pdf [Accessed 30 May 2012]. 